\title{
Phytopathogenic Fungi: Useful Tools to Degrade Plant Biomass for Bioethanol Production
}

ISSN: 2637-7659

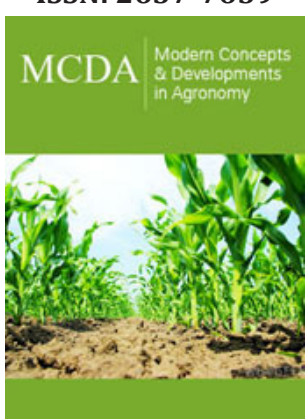

*Corresponding author: Gabriela Piccolo Maitan Alfenas, Department of Biochemistry and Molecular Biology, BIOAGRO, Federal University of Viçosa, Viçosa, MG 36.570-900, Brazil

Submission: 㘹 August 27, 2019

Published: 此 September 10, 2019

Volume 5 - Issue 1

How to cite this article: Gabriela Piccolo Maitan Alfenas, Rafael Ferreira Alfenas2and Valéria Monteze Guimarães. Phytopathogenic Fungi: Useful Tools to Degrade Plant Biomass for Bioethanol Production. Mod Concep Dev Agrono.5(1). MCDA.000604.2019.

DOI: 10.31031/MCDA.2019.05.000604

Copyright@ Gabriela Piccolo Maitan Alfenas, This article is distributed under the terms of the Creative Commons Attribution 4.0 International License, which permits unrestricted use and redistribution provided that the original author and source are credited.

\author{
Gabriela Piccolo Maitan Alfenas ${ }^{1 *}$, Rafael Ferreira Alfenas ${ }^{2}$ and Valéria Monteze \\ Guimarães ${ }^{1}$ \\ ${ }^{1}$ Department of Biochemistry and Molecular Biology, Brazil \\ ${ }^{2}$ Department of Forest Engineer, Brazil
}

\begin{abstract}
Phytopathogenic fungi are able to produce enzymes for cell wall degradation when they attack the hosts and there is a close relationship between the capacity of enzymatic secretion and the virulence of these microorganisms. These enzymes are promising for biotechnological purposes and plant biomasses play an important role for induction of their production by fungal species. Biomass is an economic alternative to reduce pollution and to produce renewable fuels. The fungal enzymes are mainly applied for the hydrolysis step of bioethanol production process, which is environmentally friend. Many phytopathogen fungi are considered promising for enzymes production such as Chrysoporthe cubensis, Ceratocystis fimbriata and Fusarium verticillioides.
\end{abstract}

\section{Introduction}

\section{Plant biomasses}

Residues from agriculture, forests and industries have highly increased with the expansion of the world population and studies stipulate that there will be around 8.5 billion of persons by 2030 in the planet, which could cause serious environmental and socioeconomic consequences [1]. However, agricultural by-products, which are lignocellulosic wastes, constitute promising renewable resources for bioethanol production since they are widely available and rich in polysaccharides as cellulose and hemicellulose [2]. The use of plant biomasses as renewable energy reduces environmental problems such as pollution and fires [1]. For bioethanol production from plant biomass, three major steps are necessary: pretreatment, hydrolysis and fermentation. Pretreatment is required to alter the biomass structure and to facilitate the enzymatic access; enzymatic hydrolysis converts polysaccharides into monomeric sugars; and fermentation turns these sugars into ethanol [3]. The enzymatic hydrolysis is the major bottleneck of the process due to the reduced efficiency and the high costs of enzymes and fungi are the main producers of the enzymes for this step [3].

\section{Phytopathogen fungi}

Due to the expansion of planted areas, selection of most productive genotypes, climate changes and transit of people and products, the occurrence of biotic diseases, especially caused by fungi has increased, leading to great damages on crop yields [4]. Nearly $10 \%$ of the identified fungal species can cause disease in more than 10,000 plants and they show different mode of actions since some fungi invade and colonize all tissues while others attack specific parts of the plants such as seeds, leaves, roots or stems [5]. Therefore, several alternatives are employed to control fungal diseases on plants, from the use of synthetic fungicides to the application of biological controls [6]. However, to cause a disease, phytopathogen fungi secrete enzymes to degrade hosts cell walls and there is a close relationship between the capacity of enzymatic secretion and the fungal pathogenicity [7]. The production of extracellular enzymes occurs not only to digest the polymers and to obtain nutrients for survival but also to degrade the cell wall barrier for penetration and spread through the plant tissue [8]. Thus, a more virulent phytopathogen shows great appeal for enzymes production. 
Worldwide interest has focused on producing enzymes from phytopathogenic fungi for several biotechnological applications, including degradation of plant biomasses, i.e. agricultural residues, for bioethanol production. Sugarcane bagasse, rice husk, soybean hulls, powder toothpick yerba mate, corn and sorghum stover and wheat bran are some of the most used biomasses for enzymatic production by fungi $[7,9,10]$. The produced enzymes are mainly applied for bioethanol production, which between the alternative energy sources, is efficient and considered environmentally friend due to its sustainable properties [1]. It is worthy to mention that plant biomasses are used to cultivate fungi and to induce their enzymatic production, but also as substrates for bioethanol production, since they can be hydrolyzed into fermented sugars.

\section{Enzymes from phytopathogenic fungi}

Many phytopathogen fungi are promising for enzymes production applied in the hydrolysis step for bioethanol production processes. Recently, our research group has published data about Chrysoporthe cubensis (Bruner) Gryzenhout \& Wingf MJ [11], Ceratocystis fimbriata Ellis \& Halst and Fusarium verticillioides (Sacc.) Nirenberg. Chrysoporthe cubensis causes Chrysoporthe canker, one of the most important diseases of Eucalyptus spp. in tropical and subtropical areas of the world [10]. This fungus releases lignocellulolytic enzymes as cellulases, hemicellulases, laccases and accessory enzymes of interest capable of efficiently catalyze the hydrolysis of plant biomasses such as sugarcane bagasse [7,9,12-14]. Ceratocystis fimbriata was firstly described by Halsted in 1980, causing sweet potato rot, and it is largely found in several environments, mainly attacking crops in tropical climate areas [15]. This fungus is able to produce an accessory enzyme, $\beta$-xylosidase, essential for hemicellulose hydrolysis of sugarcane bagasse [16]. Fusarium verticillioides cause disease on maize plantations representing a serious economic threat to its production and quality [17]. This fungus is able to secrete endoglucanase, the first enzyme to act on cellulose, and a multienzymatic complex that contains two endoglucanases, one cellobiohydrolase and one xylanase for biomass degradation [18].

\section{Final considerations}

Although we recognize the negative impact of the phytopatogenic fungi on crop yields, concerning the serious consequences of the distinct diseases, it is important to emphasize that these microorganisms are useful for biotechnological purposes, especially production of enzymes for agricultural residues degradation. These enzymes are normally induced by biomasses, which is promising for the environment and the economy, since the lignocellulosic residues are highly available non-expensive resources. Applying enzymes from phytopatogenic fungi for generation of renewable fuels is a great possibility to regenerate waste and to extract useful metabolites from these microorganisms.

\section{References}

1. Rodrigues A, Latawiec A (2018) Rethinking organic residues: the potential of biomass in Brazil. Modern Concepts \& Developments in Agronomy 1(4): 73-77.

2. Astolfi V, Astolfi AL, Mazutti MA, Rigo E, Di Luccio M, et al. (2019) Cellulolytic enzyme production from agricultural residues for biofuel purpose on circular economy approach. Bioprocess Biosyst Eng 42(5): 677-685.

3. Maitan Alfenas GP, Visser EM, Guimarães VM (2015) Enzymatic hydrolysis of lignocellulosic biomass: converting food waste in valuable products. Current Opinion in Food Science 1: 44-49.

4. Seidl R, Thom D, Kautz M, Martin Benito D, Peltoniemi M, et al. (2017) Forest disturbances under climate change. Nature Climate Change 7 : 395-402.

5. Kubicek CP, Starr TL, Glass NL (2014) Plant cell wall-degrading enzymes and their secretion in plant-pathogenic fungi. Annu Rev Phytopathol 52: 427-451.

6. Kaur T, Rani R, Manhas RK (2019) Biocontrol and plant growth promoting potential of phylogenetically new Streptomyces sp. MR14 of rhizospheric origin. AMB Express 9(1): 125.

7. Falkoski DL, Guimarães VM, de Almeida MN, Alfenas AC, Colodette JL, et al. (2013) Chrysoporthe cubensis: a new source of cellulases and hemicellulases to application in biomass saccharification processes. Bioresource Technol 130: 296-305.

8. Maitan Alfenas GP, Visser EM, Alfenas RF, Nogueira BRG, Campos GC, et al. (2015) The influence of pretreatment methods on saccharification of sugarcane bagasse by an enzyme extract from Chrysoporthe cubensis and commercial cocktails: A comparative study. Bioresour Technol 192: 670-676.

9. Orencio Trejo M, Torres Granados J, Rangel Lara A, Beltrán Guerrero E, García Aguilar S, et al. (2016) Cellulase and xylanase production by the Mexican strain Talaromyces stollii LV186 and its application in the saccharification of pretreated corn and sorghum stover. BioEnergy Research 9(4): 1034-1045.

10. Gasparotto JM, Werle LB, Mazutti MA, Foletto EL, Kuhn RC, et al. (2015) Production of cellulolytic enzymes and application of crude enzymatic extract for saccharification of lignocellulosic biomass. Appl Biochem Biotechnol 175(1): 560-572.

11. Heath RN, Gryzenhout M, Roux J, Wingfield MJ (2006) Discovery of the Canker Pathogen Chrysoporthe austroafricana on Native Syzygium spp. in South Africa. Plant Dis 90(4): 433-438.

12. De Andrade LGA, Maitan Alfenas GP, Morgan T, Gomes KS, Falkoski DL, et al. (2017) Sugarcane bagasse saccharification by purified $\beta$-glucosidases from Chrysoporthe cubensis. Biocatalysis and Agricultural Biotechnology 12: 199-205.

13. Gomes KS, Maitan Alfenas GP, de Andrade LGA, Falkoski DL, Guimarães VM, et al. (2016) Purification and characterization of xylanases from the fungus Chrysoporthe cubensis for production of xylooligosaccharides and fermentable sugars. Appl Biochem Biotechnol 182(2): 818-830.

14. Visser EM, Falkoski DL, de Almeida MN, Maitan Alfenas GP, Guimarães VM (2013) Production and application of an enzyme blend from Chrysoporthe cubensis and Penicillium pinophilum with potential for hydrolysis of sugarcane bagasse. Bioresour Technol 144: 587-594.

15. Ferreira FA, Maffia LA, Barreto RW, Demuner NL, Pigatto S (2006) Sintomatologia da murcha de Ceratocystis fimbriata em eucalipto. Revista Árvore 30(2): 155-162. 
16. Martins MP, Ventorim RZ, Coura RR, Maitan Alfenas GP, Alfenas RF, et al. (2018) The $\beta$-xylosidase from Ceratocystis fimbriata RM35 improves the saccharification of sugarcane bagasse. Biocatalysis and Agricultural Biotechnology 13: 291-298.

17. Blacutt AA, Gold SE, Voss KA, Gao M, Glenn AE (2018) Fusarium verticillioides: advancements in understanding the toxicity, virulence, and niche adaptations of a model mycotoxigenic pathogen $\mathrm{f}$ maize. Phytopathology 108(3): 312-326.
18. de Almeida MN, Falkoski DL, Guimarães VM, Ramos HJD, Visser EM, et al. (2013) Characteristics of free endoglucanase and glycosidases multienzyme complex from Fusarium verticillioides. Bioresour Technol 143: 413-422.

For possible submissions Click below: 